\title{
TNFRSF9 wt Allele
}

National Cancer Institute

\section{Source}

National Cancer Institute. TNFRSF9 wt Allele. NCI Thesaurus. Code C105112.

Human TNFRSF9 wild-type allele is located in the vicinity of 1 p36 and is approximately 21

$\mathrm{kb}$ in length. This allele, which encodes tumor necrosis factor receptor superfamily

member 9, is involved in T-cell development. 